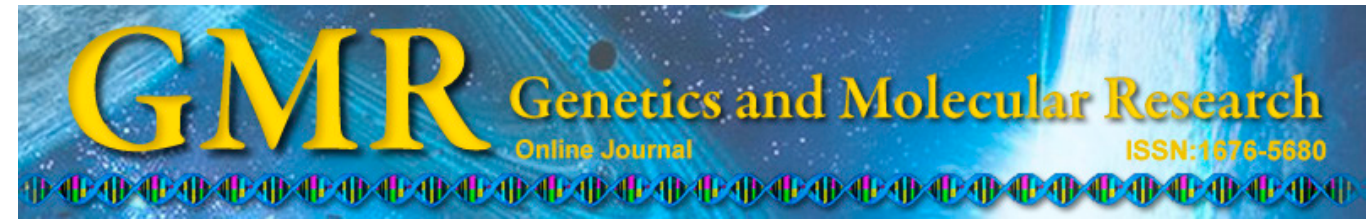

\title{
Adaptability and stability of soybean genotypes in off-season cultivation
}

\author{
R.O. Batista ${ }^{1}$, R.L. Hamawaki ${ }^{2}$, L.B. Sousa ${ }^{2}$, A.P.O. Nogueira ${ }^{3}$ and \\ O.T. Hamawaki \\ ${ }^{1}$ Departamento de Fitotecnia, Universidade Federal de Viçosa, \\ Viçosa, MG, Brasil \\ ${ }^{2}$ Instituto de Ciências Agrárias, Universidade Federal de Uberlândia, \\ Uberlândia, MG, Brasil \\ ${ }^{3}$ Instituto de Genética e Bioquímica, Universidade Federal de Uberlândia, \\ Uberlândia, MG, Brasil
}

Corresponding author: R.O. Batista

E-mail: renata_agro@yahoo.com.br

Genet. Mol. Res. 14 (3): 9633-9645 (2015)

Received January 30, 2015

Accepted May 19, 2015

Published August 14, 2015

DOI http://dx.doi.org/10.4238/2015.August.14.26

\begin{abstract}
The oil and protein contents of soybean grains are important quantitative traits for use in breeding. However, few breeding programs perform selection based on these traits in different environments. This study assessed the adaptability and stability of 14 elite early soybean breeding lines in off-season cultivation with respect to yield, and oil and protein contents. A range of statistical methods was applied and these analyses indicated that for off-season cultivation, the lines UFUS 5 and UFUS 10 could be recommended due to their superior performance in grain yield, oil content, and specific adaptability to unfavorable environments along with high stability in these characteristics. Also recommended were UFUS 06, which demonstrated superior performance in all three tested characteristics and showed adaptation to favorable environments, and UFUS 13, which showed high adaptability and stability and a superior performance for protein content.
\end{abstract}

Key words: Glycine $\max (\mathrm{L}$.$) Merril;$

Genotype x environment interaction, Grain yield; Oil content;

Protein content 


\section{INTRODUCTION}

Soybean [Glycine max (L.) Merril] is widely used both as a foodstuff and as an animal feed because of its high energy and protein content compared to other crops (Lee et al., 2013). Thus, breeding programs to improve oil and protein contents in soybean in Brazil aim to add value as well as to ensure competitiveness of the Brazilian soybean in the world market. These factors highlight the importance of evaluating quantitative traits for guiding breeding programs (Rodrigues et al., 2010). However, genotype x environment ( $\mathrm{G}$ x E) interactions hinder the selection of genotypes based on quantitative traits that have low heritability and therefore require evaluation in different environments. Several studies have reported that G x E interactions can be reduced using either specific cultivars in particular environments or cultivars with wide adaptability and stability (Ramalho et al., 2012).

In the present context, adaptability is defined as the ability of a genotype to take advantage of variations in the environment, while stability reflects the predictability of behavior of a genotype under different environmental conditions. During the final stages of evaluation and recommendation of cultivars for breeding programs, the study of adaptability and stability is essential to guide the breeder in the selection of the most appropriate genotypes (Cruz et al., 2012). Considering oil and protein traits in soybean, Nascimento et al. (2010) emphasized the difficulty of recommending genotypes for different regions due to the paucity of studies of these characteristics under Brazilian conditions.

The planting time of soybean is one of the major factors that affect grain yields (Meotti et al., 2012). Off-season planting and cultivation (or in-between harvest) is a regime in which the soybean is sown in succession to corn or another crop at the beginning of the rainy season. Usually, off-season cultivation ranges from February to March, after the summer crop harvest (Peixoto et al., 2000). Off-season cultivated soybean has not been widely adopted by growers mainly due to the lack of information and technology regarding the practice. The advantages reported in adopting the system are: i) higher selling price for the grain, ii) lower transportation costs, and iii) lower risk of rain at harvest. Santos et al. (2014) also pointed out that the lack of rain combined with low air humidity and low night temperatures favored the production of seeds with higher quality attributes. Therefore, the soybean seed price, which is higher than the price of grain, has become a major attraction for growers who adopt off-season cultivation of soybean. However, because of edaphoclimatic differences and the need for new cultivars that are adapted to new environments and planting dates, investigations are needed for each region so that the effect of $\mathrm{G} x \mathrm{E}$ interactions in the development of soybean lines or cultivars on the desired agronomic traits can be thoroughly evaluated.

The objective of this study was, therefore, to assess adaptability and stability performances of elite lines of soybeans in off-season cultivation with regard to yield, and oil and protein contents.

\section{MATERIAL AND METHODS}

Fourteen early maturing soybean lines developed by the Soybean Breeding Program of the Universidade Federal de Uberlândia and a commercial cultivar MSOY 8000, used as a check cultivar, were evaluated in four locations: Porangatu and Campo Alegre de Goiás, both in Goiás State; Buritizeiro and Uberaba, both in Minas Gerais State. A no-tillage system was 
employed, and planting was carried out in February (off-season cultivation). The geographical location, altitude, soil type, and previous crops at the experimental sites are described in Table 1.

\begin{tabular}{l} 
Table 1. Geographical location, altitude, soil type, and previous crop at each experimental site. \\
\begin{tabular}{llcll}
\hline Site & Location & Altitude $(\mathrm{m})$ & Soil & Prior crop \\
\hline Porangatu & $13^{\circ} 26^{\prime} 27^{\prime \prime} \mathrm{S}$ & Red Latosol Eutrophic & Corn \\
Campo Alegre & $49^{\circ} 8^{\prime} 56^{\prime \prime} \mathrm{W}$ & 391 & & \\
& $17^{\circ} 38^{\prime} 20^{\prime \prime} \mathrm{S}$ & & Red Latosol Dystrophic & Sorghum \\
Buritizeiro & $47^{\circ} 46^{\prime} 55^{\prime \prime} \mathrm{W}$ & 877 & Red Latosol Eutrophic & Corn \\
Uberaba & $17^{\circ} 21^{\prime} 03^{\prime \prime} \mathrm{S}$ & 538 & & \multirow{2}{*}{ Corn } \\
& $44^{\circ} 57^{\prime} 43^{\prime \prime} \mathrm{W}$ & & & \\
\hline
\end{tabular} \\
\hline
\end{tabular}

Fertilizer was applied at planting based on soil test results and recommendations for soybean cultivation (Novais et al., 1999). After sowing, the seeds were inoculated with Bradyrhizobium japonicum by spraying in the planting furrow with Biomax ${ }^{\circledR}$ in the proportion of 42 $\times 10^{8}$ bacteria cells $/ \mathrm{mL}$ of product, using $50 \mathrm{~L} / \mathrm{ha}$. Pests, diseases, and weeds were controlled by spraying with the recommended insecticides or fungicides when necessary (Sediyama, 2009).

A randomized complete block design was used for the experiment with three replications. The experimental units (plots) consisted of four rows of $5 \mathrm{~m}$, spaced $0.45 \mathrm{~m}$ apart, with a density of 300,000 plants/ha. At stage R8 of development (Fehr and Caviness, 1977) and grain moisture content of $15 \%$, plants from the two central lines were harvested but disregarding $0.50 \mathrm{~m}$ at each end of the rows. The grains were weighed to estimate yield $(\mathrm{kg} / \mathrm{ha})$. For each plot $100 \mathrm{~g}$ of grain were randomly selected and sent to the Syngenta Testing Laboratory in Uberlândia - Minas Gerais State for the analysis of oil and protein contents by Nuclear Magnetic Resonance (Colnago, 1996). The data were expressed as percentages of dry matter.

The yield values, and oil and protein contents of the soybean elite lines and the check cultivar MSOY 8000 in each environment and the $\mathrm{Gx}$ E interactions for each trait were subjected to an analysis of variance (ANOVA). Subsequently, the performance of each line was studied using other analytical methods to compare adaptability and stability for each characteristic.

One of these analytical approaches was the Eberhart and Russell method (1966) that is based on a simple linear regression analysis with an angular regression coefficient $\left(\beta_{1 i}\right)$ that is informative on the adaptability parameter and a regression deviation $\left(\hat{\sigma}^{2} \mathrm{~d}_{\mathrm{i}}\right)$ that indicates stability. Using this analytical method, information on the performance of each genotype in relation to environmental averages is obtained and this information can be used to assist selection of genotypes showing superiority in the characteristics under study (highest $\beta_{0 \mathrm{i}}$ ), wide adaptability $\left(\beta_{1 \mathrm{i}} \approx 1\right)$, and stability $\left(\hat{\sigma}^{2} \mathrm{~d}_{\mathrm{i}} \approx 0\right)$. The regression model applied was:

$$
Y_{i j}=\beta_{o i}+\beta_{1 i} \cdot I_{j}+\delta_{i j}+\bar{s}_{i j}
$$

(Equation 1)

where $Y_{i j}$ is the average of genotype $i$ in environment $j$, and $I_{j}$ is the environmental index codified according to Finlay and Wilkinson (1963) as:

$$
\text { Ij }=\frac{\sum_{\mathrm{i}} \mathrm{Y}_{\mathrm{ij}}}{\mathrm{g}}-\frac{\sum_{\mathrm{i}} \sum_{\mathrm{j}} \mathrm{Y}_{\mathrm{ij}}}{\mathrm{ge}}
$$

(Equation 2) 
where $\sum_{\mathrm{j}} \mathrm{I}_{\mathrm{j}}=0 ; \underline{\sum_{\mathrm{i}} \mathrm{Y}_{\mathrm{ij}}}$ is the average of all genotypes in environment $j$, and $\underline{\sum_{\mathrm{i}} \Sigma_{\mathrm{j}} \mathrm{Y}_{\mathrm{ij}}}$ is the general average; $g$ is the number of studied lines, and $e$ is the number of studied environments.

The parameters of adaptability $\left(\beta_{1 \mathrm{i}}\right)$ and stability $\left(\hat{\sigma}^{2} \mathrm{~d}_{\mathrm{i}}\right)$ are respectively obtained as:

$$
\beta_{1 \mathrm{i}}=\sum_{j} \mathrm{Y}_{\mathrm{ij}} \cdot \mathrm{I}_{\mathrm{j}} / \sum_{\mathrm{j}} \mathrm{I}_{\mathrm{j}}^{2}
$$

And

$$
\widehat{\sigma}^{2} \mathrm{~d}_{\mathrm{i}}=\frac{\mathrm{MS} \mathrm{S}_{\text {(deviation)i }}-\mathrm{MS}_{\mathrm{residual}}}{\mathrm{r}}
$$

(Equation 4)

where $\mathrm{MS}_{\text {(deviation)i }}=$ mean square of the average deviation of genotype $\mathrm{i}$; $\mathrm{MS}_{\text {residual }}=$ mean square of the average residual, and $\mathrm{r}=$ number of replications.

The genotypic determination coefficient $\left(\mathrm{R}^{2}\right)$ can be used as an auxiliary parameter to prevent the elimination of lines with a higher yield but low stability. This coefficient is estimated as:

$$
\mathrm{R}_{\mathrm{i}}^{2}=S S\left(\text { Linear Regression) } i / S S_{(A / G i)}\right) \times 100
$$

where $\mathrm{SS}_{\left(\mathrm{A} / \mathrm{G}_{\mathrm{i}}\right)}$ is the sum of squares of environment within genotype $\mathrm{i}$.

The analytical method proposed by Lin and Binns (1988) evaluates each line based on the parameter Pi defined as the deviation of one genotype relative to the genotype of maximum response in each environment for the factor under consideration. The most stable genotype is the one with the lowest Pi index. This parameter is obtained as:

$$
P_{i}=\frac{\sum_{j=1}^{e}\left(Y_{i j}-M_{j}\right)^{2}}{2 e}
$$

where $M_{j}$ is the maximum value of a given characteristic among all genotypes in the environment $j$ and $e$ is the number of environments.

However, Carneiro (1998) suggested decomposition of the stability and adaptability parameter $\left(\mathrm{P}_{\mathrm{i}}\right)$ for favorable and unfavorable environments. To carry this out, the environments are classified as favorable $\left(\mathrm{P}_{\text {if }}\right)$ or unfavorable $\left(\mathrm{P}_{\mathrm{iu}}\right)$ according to the environmental index of Finlay and Wilkinson (1963). In favorable $\left(I_{j}>0\right)$ and unfavorable $\left(I_{j}<0\right)$ environments, the parameters $P_{i}$ is then estimated as:

$$
P_{i f}=\frac{\sum_{j=1}^{f}\left(Y_{i j}-\bar{M}_{j}\right)^{2}}{2 f}
$$

where $f$ is the number of favorable environments, and

$$
\mathrm{P}_{\mathrm{iu}}=\frac{\sum_{\mathrm{j}=1}^{\mathrm{u}}\left(\mathrm{Y}_{\mathrm{ij}}-\overline{\mathrm{M}}_{\mathrm{j}}\right)^{2}}{2 \mathrm{u}}
$$

where $u$ is the number of unfavorable environments.

In this method, the stable genotype is the one that presents the best performance for the 
characteristics analyzed and the lowest $\mathrm{P}_{\mathrm{i}}$ index in favorable and unfavorable environments.

The centroid method proposed by Rocha et al. (2005) is based on the comparison of Cartesian distance values between the genotypes and four ideotypes based on the analyzed trait: I - general adaptability; II - specific adaptability in favorable environments; III - specific adaptability in unfavorable environments; and IV - poorly adapted. Ideotype I is characterized by maximum values in all studied environments. Ideotype II presents a maximum performance in favorable environments and a minimum performance in unfavorable environments. Ideotype III shows the opposite behavior, i.e., maximum performance in unfavorable environments and minimum performance in favorable environments. Ideotype IV has the lowest values in all environments analyzed. Classification of environments using an environmental index such as that of Finlay and Wilkinson (1963) is required to obtain the ideotypes. After this classification, the points corresponding to each ideotype are created, and the points referring to each genotype under study are plotted. With the aid of the measurement of spatial probability, the distance between each genotype and the four ideotypes is estimated by:

$$
P_{\mathrm{d}(\mathrm{i}, \mathrm{j})}=\frac{\left[\frac{1}{d i}\right]}{\sum_{i=1}^{4} \frac{1}{d i}}
$$

where $\mathrm{P}_{\mathrm{d}(\mathrm{i}, \mathrm{j})}$ is the probability of showing a pattern of stability similar to the centroid $\mathrm{j}$ and $d i$ is the distance from point $\mathrm{i}$ to centroid $\mathrm{j}$.

In this study, the joint analysis of variance and the various analyses of adaptability and stability of soybean genotypes were performed using the GENES software (Cruz, 2013).

\section{RESULTS AND DISCUSSION}

The values for yield, and oil and protein contents in grain from the different genotypes were subjected to an individual analysis of variance. The homogeneity of residual variances was checked for significance using the F-test proposed by Pimentel-Gomes (2009). A joint analysis of the four locations for the characteristics studied was then performed (Table 2). The coefficients of variation (CV) obtained for grain yield (25.49\%) were considered acceptable as this characteristic is quantitative and highly influenced by the environment (Barros et al., 2008). Pelúzio et al. (2008) reported a CV of $22.77 \%$ for grain yield, as a quantitative characteristic; this value also indicates a good control of the sources of environmental variation with regard to field trials. The CV for oil content $(1.63 \%)$ and protein content $(1.56 \%)$ were of low magnitude indicating a higher experimental precision (Table 2). Nascimento et al. (2010) observed CVs of 6.9 and $2.7 \%$ for oil and protein contents, respectively, in fifteen soybean cultivars. Although some authors have reported lower yields in off-season cultivated soybeans, the average grain yield of the UFUS soybean lines $(2,698 \mathrm{~kg} / \mathrm{ha})$ at the four sites was similar to the national average $(2,816 \mathrm{~kg} / \mathrm{ha})$ for the $2007 / 08$ growing season. Previous studies have reported yields from off-season cultivated soybean lines lower than obtained here for the UFUS lines. Lima et al. (2009) reported that the IAC-19 soybean cultivar had an average yield of $753 \mathrm{~kg} /$ ha, which is approximately one-third of the average of the UFUS lines.

The average oil content of the grain of the UFUS lines was $22.21 \%$ (Table 2). This value is larger than those in the literature regarding the potential use of soybean crop for biodiesel production (Dorneles et al., 2011). Indeed, the percentage of oil found here surpassed 
even the elite lines from the UFU Soybean Breeding Program, such as UFUS 101 (21.59\%), UFUS 106 (18.10\%), and UFUS 115 (19.52\%) (Cavalcante et al., 2011). Since 2009, following the B5 deployment in Brazil (5\% biodiesel in petroleum diesel) (Suarez et al., 2009), the oil content of soybean grain has been included as a trait of interest for breeding programs. However, to date, few studies have been carried out into this trait.

\begin{tabular}{|c|c|c|c|c|}
\hline \multirow[t]{2}{*}{ Source of variation } & \multirow[t]{2}{*}{ df } & \multicolumn{3}{|c|}{ Mean square } \\
\hline & & Grain yield & Oil content & Protein content \\
\hline Blocks/environment & 8 & $1,444,387.32$ & 0.21 & 0.51 \\
\hline Genotypes (G) & 14 & $376,275.87^{\mathrm{ns}}$ & $1.49 * *$ & $4.02 * *$ \\
\hline Environments (E) & 3 & $10,225,612.28 *$ & $10.40 * *$ & $13.08 * *$ \\
\hline G x E interaction & 42 & $805,334.87 *$ & $0.97 * *$ & $03.08 * *$ \\
\hline Error & 112 & $473,012.65$ & 0.13 & 0.41 \\
\hline Average & & $2,697.84$ & 22.21 & 41.10 \\
\hline $\mathrm{CV}(\%)$ & & 25.49 & 1.63 & 1.56 \\
\hline
\end{tabular}

ns $=$ Non-significant; ${ }^{* * *}$ Significant at 1 and $5 \%$ levels, respectively, by the $\mathrm{F}$ test.

The protein content of the grain averaged $41.10 \%$. Comparing to the commercial soybean cultivars of the 1990s cited by Mascarenhas et al. (1990), the UFUS lines showed an approximately $7 \%$ increase in grain protein content. The performance of the UFUS lines with regard to grain protein content is of interest for breeding programs due to the increased demand for soybean meal with higher protein contents (Moraes et al., 2006). The significant $G$ $x$ E interaction indicated that the lines had clearly different performances under the different environmental conditions in the four locations, thus justifying the study of the performance of the genotypes using adaptability and stability analyses (Table 2). Polizel et al. (2013) emphasized the importance of such analyses in the final stages of a soybean breeding program since, for recommendation of high yielding genotypes, high stability and wide adaptability are of major importance for soybean growers.

According to the analytical method proposed by Eberhart and Russell (1966), the ideal genotype is one that presents a high average for the analyzed trait, a regression coefficient $\left(\beta_{1 \mathrm{i}}\right)$ equal to 1.0 , and a regression deviation $\left(\widehat{\sigma}^{2} \mathrm{~d}_{\mathrm{i}}\right)$ as small as possible (equal to zero). As described in Table 3, none of the regression coefficients were significant in a $t$-test, indicating high adaptability, i.e. the presence of a genotype able to respond positively to environmental improvements (Cruz et al., 2012). Genotypes with this response pattern are considered ideotypes and therefore can be recommended for regions with high or low technological levels as they will maintain their level of performance. This result is of relevance to Porangatu and Buritizeiro, which have negative environmental indices and were designated as unfavorable environments. In these environments, the behavior of a genotype with specific requirements and low adaptability would be hampered and its genetic potential underestimated.

In the analytical method of Lin and Binns (1988) as modified by Carneiro (1998), the decomposition of the Pi parameter provides insight into the behavior of the genotypes in favorable and unfavorable environments. Under this method, the best genotype is considered to be the one with the greatest performance and the lowest value of Pi. Here, we found that most UFUS lines showed lower unfavorable Pi values, indicating greater adaptability to these environments. The exceptions were lines UFUS 01 and UFUS 02 , which were adapted to favorable 
environments (Table 3). These two lines were also those with the highest yield, followed by UFUS 10, UFUS 05 , and UFUS 06 which demonstrated specific adaptability to unfavorable environments. The methods of Eberhart and Russell (1966) and Lin and Binns (1988)/Carneiro (1998) did not agree about the classification of all genotypes with regard to grain yield. Nevertheless, genotypic adaptability to unfavorable environments as described under the Lin and Binns (1988)/Carneiro (1998) analytical approach is relevant for the planting season for which these genotypes are being evaluated and recommended (i.e. off-season cultivation).

\begin{tabular}{|c|c|c|c|c|c|c|c|}
\hline \multirow[t]{2}{*}{ Genotypes } & \multirow{2}{*}{$\begin{array}{l}\text { Mean grain yield } \\
(\mathrm{kg} / \mathrm{ha})\end{array}$} & \multicolumn{3}{|c|}{ Eberhart and Russell (1966) } & \multicolumn{3}{|c|}{ Lin and Binns (1988)/Carneiro (1998) } \\
\hline & & $\widehat{\boldsymbol{\beta}}_{1 \mathrm{i}}$ & $\widehat{\sigma}^{2} \mathbf{d}_{\mathrm{i}}$ & $\mathrm{R}^{2}(\%)$ & $\mathrm{Pi}_{\text {general }}$ & $\mathrm{Pi}_{\text {favorable }}$ & $\mathrm{Pi}_{\text {unfavorable }}$ \\
\hline UFUS 01 & 2907.0 & $1.58^{\text {ns }}$ & $-87,941.3^{\text {ns }}$ & 92.44 & $432,580.8$ & $276,892.3$ & $322,529.3$ \\
\hline UFUS 02 & 2972.6 & $1.60^{\mathrm{ns}}$ & $-25,108.9^{\text {ns }}$ & 86.85 & $417,184.2$ & $252,087.6$ & $295,936.0$ \\
\hline UFUS 03 & 2767.0 & $1.33^{\text {ns }}$ & $-118,871.1^{\mathrm{ns}}$ & 93.92 & $470,592.1$ & $426,414.0$ & $389,623.4$ \\
\hline UFUS 04 & 2566.5 & $0.79^{\text {ns }}$ & $-106,489.7^{\mathrm{ns}}$ & 80.56 & $755,493.8$ & $997,625.8$ & $557,245.0$ \\
\hline UFUS 05 & 2835.1 & $0.23^{\text {ns }}$ & $-41,486.7^{\mathrm{ns}}$ & 12.99 & $633,404.4$ & $709,301.5$ & $514,770.2$ \\
\hline UFUS 06 & 2822.1 & $0.81^{\mathrm{ns}}$ & $-121,619.6^{\mathrm{ns}}$ & 86.11 & $495,940.2$ & $546,640.6$ & $495,848.8$ \\
\hline UFUS 07 & 2768.9 & $0.48^{\text {ns }}$ & $549,681.8 *$ & 09.86 & $646,780.9$ & $944,279.5$ & $534,653.6$ \\
\hline UFUS 08 & 2797.7 & $1.18^{\mathrm{ns}}$ & $-110,861.8^{\mathrm{ns}}$ & 91.01 & $478,204.6$ & $492,921.0$ & $409,768.6$ \\
\hline UFUS 09 & 2451.5 & $0.88^{\mathrm{ns}}$ & $43,427.6^{\mathrm{ns}}$ & 57.03 & $985,807.3$ & $1,152,925.3$ & $833,736.3$ \\
\hline UFUS 10 & 2897.0 & $1.73^{\mathrm{ns}}$ & $1,012,618.5^{* *}$ & 46.53 & $519,018.6$ & $602,257.0$ & $499,993.9$ \\
\hline UFUS 11 & 2504.1 & $0.80^{\text {ns }}$ & $15,402.0^{* *}$ & 55.64 & $832,650.1$ & $1,026,918.4$ & $588,269.4$ \\
\hline UFUS 12 & 2589.6 & $0.88^{\text {ns }}$ & $413,322.5^{*}$ & 31.67 & $855,085.2$ & $1,130,646.7$ & $761,804.4$ \\
\hline UFUS 13 & 2568.5 & $0.89^{\text {ns }}$ & $491,990.9^{*}$ & 29.51 & $743,844.6$ & $987,695.2$ & $545,116.3$ \\
\hline UFUS 14 & 2584.9 & $0.96^{\mathrm{ns}}$ & $132,068.2^{\mathrm{ns}}$ & 52.15 & $771,518.9$ & $1,015,138.8$ & $582,280.8$ \\
\hline MSOY 8000 & 2434.6 & $0.86^{\mathrm{ns}}$ & $399,451.7^{*}$ & 31.21 & $1,138,360.9$ & $1,514,917.5$ & $944,696.3$ \\
\hline
\end{tabular}

$\mathrm{ns}=$ Non-significant. ${ }^{* * *}$ Significant at 1 and $5 \%$ levels of probability, respectively, by the $\mathrm{F}$ test.

In the centroid method, which is based on analysis of principal components, the discrimination of genotypes is determined by their adaptation to distinct environmental groups (i.e. favorable or unfavorable) (Rocha et al., 2005). The lines UFUS 01 and UFUS 02 were both grouped in ideotype II (specific adaptability to favorable environments) but were nevertheless promising materials as they had the highest average grain yield as well as high adaptability and high stability according to the classification provided by the Eberhart and Russell (1966) method (Table 4). UFUS 10, which was ranked as the third most productive line, was classified as adapted to favorable environments according by the centroid method, whereas by the Lin and Binns (1988)/Carneiro (1998) method its adaptation was specific to unfavorable environments. The UFUS 05 genotype was classified as ideotype III indicating specific adaptability to unfavorable environments; the same classification was produced by the Lin and Binns (1988)/Carneiro (1998) method. This information is relevant not only because of the presence of locations with a negative environmental index (Porangatu and Buritizeiro), but also because this lineage was ranked as the fourth for yield trait. Despite the restricted classification of UFUS 01 , UFUS 02 , UFUS 05 , and UFUS 10 as showing specific adaptability to favorable or unfavorable environments, it is important to highlight the conditions under which these genotypes were evaluated, i.e., grown in a non-recommended planting season and in environments not previously used for these lines. These conditions allowed expression of genetic potential in these lines during off-season cultivation as evidenced by their good yield performance and their superiority compared to the check cultivar 'MSOY 8000'. This improved 
behavior might be attributed to various factors, such as the presence of "long juvenility" alleles in UFUS lines. The expression of these gene variants under conditions of suboptimal photoperiod for flowering stimulation, may allow the plants to maintain vegetative growth. This might allow increased accumulation of biomass that is ultimately transferred to the grain.

\begin{tabular}{|c|c|c|c|c|c|c|}
\hline \multirow[t]{2}{*}{ Genotypes } & \multirow[t]{2}{*}{ Mean grain yield } & \multirow[t]{2}{*}{ Ideotype } & \multicolumn{4}{|c|}{ Centroid $^{1}$} \\
\hline & & & Prob (I) & Prob (II) & Prob (III) & Prob (IV) \\
\hline UFUS 01 & 2907.04 & II & 0.26 & 0.35 & 0.18 & 0.21 \\
\hline UFUS 02 & 2972.67 & II & 0.27 & 0.35 & 0.18 & 0.20 \\
\hline UFUS 03 & 2767.08 & II & 0.24 & 0.30 & 0.21 & 0.25 \\
\hline UFUS 04 & 2566.50 & IV & 0.19 & 0.22 & 0.26 & 0.33 \\
\hline UFUS 05 & 2835.10 & III & 0.23 & 0.21 & 0.30 & 0.26 \\
\hline UFUS 06 & 2822.13 & IV & 0.25 & 0.25 & 0.25 & 0.25 \\
\hline UFUS 07 & 2768.94 & III & 0.23 & 0.19 & 0.34 & 0.24 \\
\hline UFUS 08 & 2797.71 & II & 0.25 & 0.27 & 0.23 & 0.25 \\
\hline UFUS 09 & 2451.56 & IV & 0.18 & 0.23 & 0.22 & 0.36 \\
\hline UFUS 10 & 2897.06 & II & 0.27 & 0.32 & 0.19 & 0.21 \\
\hline UFUS 11 & 2504.15 & IV & 0.19 & 0.21 & 0.27 & 0.34 \\
\hline UFUS 12 & 2589.60 & IV & 0.21 & 0.22 & 0.27 & 0.30 \\
\hline UFUS 13 & 2568.52 & IV & 0.21 & 0.24 & 0.26 & 0.30 \\
\hline UFUS 14 & 2584.92 & IV & 0.21 & 0.26 & 0.23 & 0.31 \\
\hline MSOY 8000 & 2434.63 & IV & 0.19 & 0.22 & 0.24 & 0.34 \\
\hline
\end{tabular}

${ }^{1}$ I: general adaptability; II: specific adaptability to favorable environments; III: specific adaptability to unfavorable environments; IV: poorly adapted.

Analysis of the grain oil contents showed that eight UFUS lines were classified as having general adaptability (Eberhart and Russell, 1966), including UFUS 10 and UFUS 02, which were first and sixth most productive for this trait (Table 5). Among these genotypes with general adaptability, only UFUS 05 and UFUS 13 showed high stability. In addition to productivity, UFUS 05 showed specific adaptability to unfavorable environments, a valuable characteristic for off-season cultivation. In addition to having high oil content, the UFUS 06 line showed specific adaptability to favorable environments. The UFUS 04 line stood out because of its high oil content in the grain, adaptability to unfavorable environments, and high stability; these characteristics make it an interesting option for breeding for oil content. Also noteworthy was UFUS 10 which, in addition to being the line with the highest oil content in the grain, showed general adaptability (Eberhart and Russell, 1966) and had the third highest grain yield, resulting in a higher oil yield per hectare. Ten UFUS lines showed specific adaptability to favorable environments by the Lin and Binns (1988)/Carneiro (1998) method including UFUS 10 and UFUS 06 that were classified as lines with high oil contents in the grain (Table 5). For this characteristic, both Eberhart and Russell (1966) and Lin and Binns (1988)/Carneiro (1998) methods were consistent in describing UFUS 06 as showing specific adaptability to favorable environments and UFUS 04 to unfavorable environments. Among the six most productive breeding lines with regard oil content, UFUS 02, UFUS 10, and UFUS 06 were also ranked as first, third, and fifth places, respectively, for yield.

The centroid method classified lines UFUS 02, UFUS 06, UFUS 10, and UFUS 11 as having high adaptability and similarity to ideotype I for oil contents (Table 6). Lines UFUS 01, UFUS 04, and UFUS 05 and the check cultivar MSOY 8000, also had superior performance with respect to oil content when compared with the overall average and were 
Table 5. Mean oil contents (\%) and estimates of the parameters for adaptability and stability in 15 soybean genotypes at four experimental sites.

\begin{tabular}{|c|c|c|c|c|c|c|c|}
\hline \multirow[t]{2}{*}{ Genotypes } & \multirow[t]{2}{*}{ Mean oil content $(\%)$} & \multicolumn{3}{|c|}{ Eberhart and Russell (1966) } & \multicolumn{3}{|c|}{ Lin and Binns (1988)/Carneiro (1998) } \\
\hline & & $\widehat{\beta}_{1 \mathrm{i}}$ & ${\widehat{\sigma_{\mathrm{di}}}}^{2}$ & $\mathrm{R}^{2}(\%)$ & $\mathrm{Pi}_{\text {general }}$ & $\mathrm{Pi}_{\text {favorable }}$ & $\mathrm{Pi}_{\text {unfavorable }}$ \\
\hline UFUS 01 & 22.29 & $0.09^{++}$ & $0.16^{*}$ & 1.32 & 0.47 & 0.99 & 0.30 \\
\hline UFUS 02 & 22.31 & $1.09^{\mathrm{ns}}$ & $0.15^{*}$ & 68.35 & 0.53 & 0.20 & 0.63 \\
\hline UFUS 03 & 22.09 & $1.87^{++}$ & $0.08^{\text {ns }}$ & 90.43 & 0.67 & 0.98 & 0.87 \\
\hline UFUS 04 & 22.53 & $-0.01^{++}$ & $0.04^{\mathrm{ns}}$ & 0.08 & 0.26 & 0.87 & 0.10 \\
\hline UFUS 05 & 22.29 & $0.58^{\text {ns }}$ & $-0.02^{\mathrm{ns}}$ & 82.87 & 0.47 & 0.57 & 0.43 \\
\hline UFUS 06 & 22.71 & $1.57^{+}$ & $0.79 * *$ & 50.77 & 0.23 & 0.00 & 0.31 \\
\hline UFUS 07 & 21.69 & $1.23^{\mathrm{ns}}$ & $0.15^{*}$ & 73.37 & 1.26 & 0.66 & 1.46 \\
\hline UFUS 08 & 22.21 & $1.64^{+}$ & $0.89 * *$ & 49.92 & 0.70 & 0.18 & 0.88 \\
\hline UFUS 09 & 21.98 & $0.63^{\text {ns }}$ & $0.48 * *$ & 20.64 & 0.98 & 0.74 & 1.06 \\
\hline UFUS 10 & 22.74 & $1.14^{\mathrm{ns}}$ & $0.21 * *$ & 63.64 & 0.11 & 0.03 & 1.14 \\
\hline UFUS 11 & 22.40 & $2.02^{++}$ & $0.08^{\mathrm{ns}}$ & 91.86 & 0.47 & 0.00 & 0.62 \\
\hline UFUS 12 & 22.07 & $1.22^{\mathrm{ns}}$ & $0.39^{* *}$ & 54.03 & 0.87 & 0.36 & 1.03 \\
\hline UFUS 13 & 21.78 & $0.81^{\mathrm{ns}}$ & $0.01^{\mathrm{ns}}$ & 80.11 & 1.00 & 0.96 & 1.03 \\
\hline UFUS 14 & 21.54 & $0.72^{\text {ns }}$ & $0.79 * *$ & 17.92 & 1.72 & 1.43 & 1.82 \\
\hline MSOY 8000 & 22.46 & $0.39^{+}$ & $0.10^{*}$ & 27.35 & 0.30 & 0.52 & 0.23 \\
\hline
\end{tabular}

ns = Non-significant; $\left(\left(^{+}\right)\right.$and $\left(^{+}\right)$significant at 1 and $5 \%$ levels of probability, respectively, by $t$-test; **,*Significant at 1 and $5 \%$ levels of probability respectively by the $\mathrm{F}$ test.

classified as ideotype III (specific adaptability to unfavorable environments). The centroid method was effective at discriminating lines by their oil content performance and classified the genotypes into ideotypes I or III with higher oil contents or into ideotypes II or IV with lower oil contents. For genotypes with higher oil contents (i.e., UFUS 10, UFUS 06, UFUS 04, UFUS 11, and UFUS 02), the adaptability classification was consistent in at least two of the three analytical methods. The highest yielding line, UFUS 10, for example, was classified as having general adaptability by both Eberhart and Russell (1966) and centroid methods. The second most productive line, UFUS 06, was classified as showing specific adaptability to favorable environments by Eberhart and Russell (1966) and Lin and Binns (1988)/Carneiro (1998). UFUS 04 (the third most productive line) showed specific adaptability to unfavorable environments in all three methods. UFUS 02 (sixth highest oil content) showed general adaptability by Eberhart and Russell (1966) and centroid methods. With regard to these four lines, it is worth mentioning that the oil content in each was higher than the average levels reported for genotypes with high potential for biodiesel production (Cavalcante et al., 2011; Dorneles et al., 2011). In addition, UFUS 02, UFUS 06, and UFUS 10 also excelled for grain yield, giving these lines great potential as cultivars for off-season cultivation and for use as parental lines in breeding programs. Silva (2013) highlighted the fact that the soybean crop worldwide contributes to $29.4 \%$ of the vegetable oil market and that this production is primarily intended for human consumption or as raw material for the production of biodiesel.

With regard to protein content in the grain, seven of the fourteen UFUS lines and MSOY 8000 had high adaptability by the method of Eberhart and Russell (1966) (Table 7). UFUS 13 was found to be the line with highest protein content in the grain, to have general adaptability, and to be very stable. Lines UFUS 14 and UFUS 12 were second and third most productive for protein content and also had high adaptability; however, the analysis indicated that they were rather unstable. Line UFUS 05, which also showed promise for other traits, showed general adaptability and higher than average protein content in grain. UFUS 07 , which ranked fourth for grain yield, and was also considered to have enhanced protein production, showed high stability and specific adaptability to unfavorable environments. 
Table 6. Mean oil contents (\%), ideotype classification by the centroid method, and probability of association to ideotype in 15 soybean genotypes at four experimental sites.

\begin{tabular}{|c|c|c|c|c|c|c|}
\hline \multirow[t]{2}{*}{ Genotypes } & \multirow[t]{2}{*}{ Mean oil content $(\%)$} & \multirow[t]{2}{*}{ Ideotype } & \multicolumn{4}{|c|}{ Centroid $^{1}$} \\
\hline & & & Prob (I) & Prob (II) & Prob (III) & Prob (IV) \\
\hline UFUS 01 & 22.29 & III & 0.27 & 0.17 & 0.38 & 0.19 \\
\hline UFUS 02 & 22.31 & I & 0.27 & 0.25 & 0.25 & 0.23 \\
\hline UFUS 03 & 22.09 & II & 0.23 & 0.31 & 0.21 & 0.25 \\
\hline UFUS 04 & 22.53 & III & 0.27 & 0.12 & 0.47 & 0.13 \\
\hline UFUS 05 & 22.29 & III & 0.27 & 0.21 & 0.30 & 0.22 \\
\hline UFUS 06 & 22.71 & I & 0.41 & 0.18 & 0.26 & 0.16 \\
\hline UFUS 07 & 21.69 & IV & 0.15 & 0.30 & 0.16 & 0.38 \\
\hline UFUS 08 & 22.21 & II & 0.26 & 0.26 & 0.24 & 0.24 \\
\hline UFUS 09 & 21.98 & IV & 0.22 & 0.26 & 0.24 & 0.29 \\
\hline UFUS 10 & 22.74 & I & 0.47 & 0.14 & 0.26 & 0.13 \\
\hline UFUS 11 & 22.40 & I & 0.29 & 0.28 & 0.22 & 0.21 \\
\hline UFUS 12 & 22.07 & IV & 0.21 & 0.29 & 0.21 & 0.29 \\
\hline UFUS 13 & 21.78 & IV & 0.19 & 0.26 & 0.22 & 0.34 \\
\hline UFUS 14 & 21.54 & IV & 0.15 & 0.26 & 0.16 & 0.43 \\
\hline MSOY8000 & 22.46 & III & 0.31 & 0.16 & 0.36 & 0.17 \\
\hline
\end{tabular}

${ }^{1}$ Ideotype I has general adaptability; ideotype II has specific adaptability to favorable environments; ideotype III has specific adaptability to unfavorable environments; ideotype IV is poorly adapted.

Using the Pi parameter (Lin and Binns, 1988; Carneiro, 1998), eight UFUS genotypes demonstrated specific adaptability to favorable environments and six to unfavorable environments. UFUS 13, which was the most productive line for protein content, showed specific adaptability to favorable environments; this line showed general adaptability and high stability by the Eberhart and Russell (1966) method. UFUS 14 and UFUS 12, both of which had high protein content in the grain, showed specific adaptability to unfavorable and favorable environments respectively, However, they were classified as general adaptability by the Eberhart and Russell (1966) method. The lines UFUS 07 and 06, which ranked fourth and fifth for protein content, showed similar behaviors by Linn and Binns (1966)/Carneiro (1998) and Eberhart and Russell (1966) and were classified as having specific adaptability to unfavorable (UFUS 07) and favorable environments (UFUS 06). The similarity of the two analytical methodologies for distinguishing adaptability in UFUS genotypes was more frequent for the least productive lines.

Table 7. Mean protein contents (\%) and estimates of the parameters for adaptability and stability in 15 soybean genotypes at four experimental sites.

\begin{tabular}{|c|c|c|c|c|c|c|c|}
\hline \multirow[t]{2}{*}{ Genotypes } & \multirow[t]{2}{*}{ Mean protein content $(\%)$} & \multicolumn{3}{|c|}{ Eberhart and Russell (1966) } & \multicolumn{3}{|c|}{ Lin and Binns (1988)/Carneiro (1998) } \\
\hline & & $\widehat{\boldsymbol{\beta}}_{1 \mathrm{i}}$ & $\widehat{\sigma}_{\mathrm{di}}^{2}$ & $\mathrm{R}^{2}(\%)$ & $\mathrm{Pi}_{\text {general }}$ & $\mathrm{Pi}_{\text {favorable }}$ & $\mathrm{Pi}_{\text {unfavorable }}$ \\
\hline UFUS 01 & 40.77 & $0.81^{\text {ns }}$ & $0.47 *$ & 32.48 & 2.63 & 2.98 & 2.27 \\
\hline UFUS 02 & 40.25 & $-0.27^{++}$ & $0.21^{\mathrm{ns}}$ & 08.45 & 3.90 & 5.44 & 2.35 \\
\hline UFUS 03 & 41.11 & $1.78^{+}$ & $0.08^{\mathrm{ns}}$ & 86.90 & 1.59 & 1.03 & 2.15 \\
\hline UFUS 04 & 40.60 & $1.29^{\mathrm{ns}}$ & $0.89 * *$ & 42.24 & 3.12 & 2.72 & 3.52 \\
\hline UFUS 05 & 41.32 & $0.70^{\mathrm{ns}}$ & $0.68 * *$ & 21.31 & 1.72 & 2.25 & 1.18 \\
\hline UFUS 06 & 41.53 & $2.64^{++}$ & $0.94 * *$ & 74.43 & 1.22 & 0.48 & 1.97 \\
\hline UFUS 07 & 41.57 & $0.08^{+}$ & $-0.10^{\mathrm{ns}}$ & 07.40 & 1.05 & 1.66 & 0.44 \\
\hline UFUS 08 & 40.76 & $1.82^{+}$ & $0.55^{* *}$ & 68.47 & 2.41 & 1.51 & 3.31 \\
\hline UFUS 09 & 40.85 & $-1.37^{++}$ & $0.44 *$ & 59.09 & 3.12 & 5.73 & 0.52 \\
\hline UFUS 10 & 40.01 & $2.11^{++}$ & $0.56^{* *}$ & 74.06 & 4.28 & 2.96 & 5.60 \\
\hline UFUS 11 & 41.23 & $1.59^{\mathrm{ns}}$ & $1.41 * *$ & 42.37 & 1.69 & 0.96 & 2.43 \\
\hline UFUS 12 & 41.80 & $1.22^{\mathrm{ns}}$ & $0.83^{* *}$ & 40.60 & 0.89 & 0.72 & 1.05 \\
\hline UFUS 13 & 41.92 & $1.29^{\mathrm{ns}}$ & $0.20^{\mathrm{ns}}$ & 68.50 & 0.65 & 0.45 & 0.86 \\
\hline UFUS 14 & 41.87 & $0.48^{\mathrm{ns}}$ & $1.17 * *$ & 07.31 & 1.00 & 1.28 & 0.72 \\
\hline MSOY 8000 & 40.97 & $0.84^{\text {ns }}$ & $4.73 * *$ & 06.13 & 2.77 & 3.00 & 2.52 \\
\hline
\end{tabular}

$\mathrm{ns}=$ Non-significant; $\left({ }^{++}\right)$and $\left(^{+}\right)$significant at 1 and $5 \%$ levels of probability, respectively, by $t$-test; $* *, *$ Significant at 1 and $5 \%$ levels of probability respectively by the $\mathrm{F}$ test. 
By the centroid method, the four genotypes with the highest protein content in the grain, (UFUS 13, UFUS 14, UFUS 12, and UFUS 07) clustered with ideotype I and showed general adaptability (Table 8 ). The less productive lines clustered with ideotype IV, whose behavior was considered poorly adapted. Line UFUS 06 , the fifth most productive for protein content, was classified as ideotype II and showed specific adaptability to favorable environments by all three methodologies in this study (Tables 7 and 8). Moreover, the three most productive lines (UFUS 13, UFUS 14, and UFUS 12) also had high adaptability according the Eberhart and Russell (1966) method. The centroid method gave a similar result for lines UFUS 03, UFUS 06, UFUS 08, and UFUS 09 as the Lin and Binns (1988)/Carneiro (1998) and Eberhart and Russell (1966) methods (Table 7).

Comparison with previously reported data on commercial cultivars of the 1990s (Mascarenhas et al., 1990) indicated that the UFUS lines showed an approximately 7\% increase in protein content. Souza et al. (2009) obtained an average of 35\% protein in an assessment of the BRS 206 cultivar. Thus, the performance of the UFUS lines for this characteristic is of interest for breeding programs due to the increasing global demand for soybean meal with higher protein contents for animal feed.

\begin{tabular}{|c|c|c|c|c|c|c|}
\hline \multirow[t]{2}{*}{ Genotypes } & \multirow[t]{2}{*}{ Mean protein content (\%) } & \multirow[t]{2}{*}{ Ideotype } & \multicolumn{4}{|c|}{ Centroid $^{1}$} \\
\hline & & & Prob (I) & Prob (II) & Prob (III) & Prob (IV) \\
\hline UFUS 01 & 40.77 & IV & 0.22 & 0.25 & 0.24 & 0.29 \\
\hline UFUS 02 & 40.25 & IV & 0.16 & 0.18 & 0.28 & 0.38 \\
\hline UFUS 03 & 41.11 & II & 0.26 & 0.32 & 0.20 & 0.22 \\
\hline UFUS 04 & 40.60 & IV & 0.20 & 0.27 & 0.22 & 0.31 \\
\hline UFUS 05 & 41.32 & I & 0.28 & 0.25 & 0.25 & 0.23 \\
\hline UFUS 06 & 41.53 & II & 0.30 & 0.36 & 0.17 & 0.17 \\
\hline UFUS 07 & 41.57 & I & 0.32 & 0.21 & 0.28 & 0.19 \\
\hline UFUS 08 & 40.76 & II & 0.23 & 0.31 & 0.21 & 0.26 \\
\hline UFUS 09 & 40.85 & III & 0.19 & 0.16 & 0.41 & 0.24 \\
\hline UFUS 10 & 40.01 & IV & 0.16 & 0.28 & 0.18 & 0.38 \\
\hline UFUS 11 & 41.23 & II & 0.28 & 0.29 & 0.22 & 0.22 \\
\hline UFUS 12 & 41.80 & I & 0.37 & 0.25 & 0.21 & 0.18 \\
\hline UFUS 13 & 41.92 & I & 0.40 & 0.24 & 0.19 & 0.16 \\
\hline UFUS 14 & 41.87 & I & 0.37 & 0.22 & 0.24 & 0.18 \\
\hline MSOY 8000 & 40.97 & III & 0.25 & 0.25 & 0.25 & 0.25 \\
\hline
\end{tabular}

${ }^{1}$ Ideotype I has general adaptability; ideotype II has specific adaptability to favorable environments; ideotype III has specific adaptability to unfavorable environments; ideotype IV is poorly adapted.

Regarding grain protein content, no agreement has been reached on the relationship of this trait to grain yield as is evident for oil content. Thus, the strategies suggested are: i) direct selection for grain yield with gain in oil content for biodiesel production, or ii) specific selection for increased protein content in soybean meal. The UFUS 10 and UFUS 05 lines can be recommended for planting in off-season cultivation of soybeans due to their better performance in both grain yield and oil content and the associated traits of general and specific adaptability to unfavorable environments for these characteristics. The UFUS 06 line showed superior performance in the three characteristics and proven to be specifically adapted to favorable environments. For protein content in the grain, the UFUS 13 genotype was found to be well adapted, stable and to have a high performance. 


\title{
Conflicts of interest
}

\author{
The authors declare no conflict of interest.
}

\section{REFERENCES}

Barros HB, Sediyama T, Teixeira RC and Cruz CD (2008). Análises paramétricas e não-paramétricas para determinação da adaptabilidade e estabilidade de genótipos de soja. Sci. Agr. 9: 299-309.

Carneiro PCS (1998). Novas metodologias de análise de adaptabilidade e estabilidade de comportamento. Universidade Federal de Viçosa, Viçosa.

Cavalcante AK, Sousa LB and Hamawaki OT (2011). Determinação e avaliação do teor de óleo em sementes de soja pelos métodos de ressonância magnética nuclear e soxhlet. Biosci. J. 27: 8-15.

Colnago LA (1996). Análise do teor de óleo em sementes por RMN. Embrapa Instrumentação Agropecuária, São Carlos.

Cruz CD (2013). GENES - a software package for analysis in experimental statistics and quantitative genetics. Acta Sci. Agron. 35: 271-276.

Cruz CD, Regazzi AJ and Carneiro PCS (2012). Modelos biométricos aplicados ao melhoramento genético. Editora UFV, Viçosa, 514.

Dorneles LMC, Hamawaki OT, Rezende DF, Sousa LB, et al. (2011). Produtividade de grãos e óleo em linhagens de soja semiprecoce no estado de Goiás, safra 2009/2010. Rev. Verde Agroecol. Desenv. Sustentável 6: 38-42.

Eberhart ST and Russell WA (1966). Stability parameters for comparing varieties. Crop Sci. 6: 36-40.

Fehr WR and Caviness CE (1977). Stages of soybean development. Iowa State University of Science and Technology. Ames, Iowa.

Finlay K and Wilkinson G (1963). The analysis of adaptation in a plant-breeding programme. Aust. J. Agric. Res. 14: 742-754.

Lee H, Cho B-K, Kim MS, Lee W-H, et al. (2013). Prediction of crude protein and oil content of soybeans using Raman spectroscopy. Sensors Actuators B: Chemical 185: 694-700.

Lima EV, Crusciol CAC, Cavariani C and Nakagawa J (2009). Características agronômicas, produtividade e qualidade fisiológica da soja "safrinha" sob semeadura direta, em função da cobertura vegetal e da calagem superficial. Rev. Bras. Sementes 31: 69-80.

Lin CS and Binns MR (1988). A superiority measure of cultivar performance for cultivar x location data. Can. J. Plant Sci. 68: 193-198.

Mascarenhas HAA, Teixeira JPF, Nagai V, Tanaka RT, et al. (1990). Calagem nos teores de óleo e de proteína em soja. Bragantia 49: 171-182.

Meotti GV, Benin B, Silva RR, Beche E, et al. (2012). Épocas de semeadura e desempenho agronômico de cultivares de soja. Pesq. Agropec. Bras. 47: 14-21.

Moraes RMA, José IC, Ramos FG, Barros EG et al. (2006). Caracterização bioquímica de linhagens de soja com alto teor de proteína. Pesq. Agropec. Bras. 41: 725-729.

Nascimento M, Finoto EL, Sediyama T and Cruz CD (2010). Adaptability and stability of soybean in terms of oil and protein content. Crop Breed. Appl. Biotechnol. 10: 48-54.

Novais R, Ribeiro A, Guimarães P, Alvarez V (1999). Soja. In: Recomendações para o uso de corretivos e fertilizantes em Minas Gerais - $5^{\circ}$ Aproximação (Ribeiro A, Guimarães P and Alvarez V, eds.). Editora UFV, Viçosa, 359.

Peixoto CP, Câmara GMS, Martins MC, Marchiori LFS, et al. (2000). Épocas de semeadura e densidade de plantas de soja: I. Componentes da produção e rendimento de grãos. Sci. Agric. 57: 89-96.

Pelúzio JM, Fidelis RR, Giongo P, da Silva JC, et al. (2008). Adaptabilidade e estabilidade de cultivares de soja em quatro épocas de semeadura no sul do Estado do Tocantins. Rev. Ceres 55: 34-40.

Pimentel-Gomes F (2009). Curso de estatística experimental. Editora Fealq, Piracicaba 430.

Polizel AC, Juliatti FC, Hamawaki OT, Hamawaki RL, et al. (2013). Adaptabilidade e estabilidade fenotípica de genótipos de soja no estado do Mato Grosso. Biosci. J. 29: 910-920.

Ramalho M, Abreu A, Santos J and Nunes J (2012). Aplicações da genética quantitativa no melhoramento de plantas autógamas. Editora UFLA, Lavras.

Rocha RB, Muro-Abad JI, Araújo EF and Cruz CD (2005). Avaliação do método centróide para estudo de adaptabilidade ao ambiente de clones de Eucalyptus grandis. Cienc. Florestal 15: 255-266.

Rodrigues JIS, Miranda FD, Ferreira A, Borges LL, et al. (2010). Mapeamento de QTL para conteúdos de proteína e óleo em soja. Pesq. Agropec. Bras. Brasília 45: 472-480. 
Santos WF, Santos DSS, Pelúzio JM, Reina E, et al. (2014). Teores de lipídeo e proteína em grãos de soja visando aplicação industrial. Tecnol. Cienc. Agropec. 8: 61-64.

Sediyama T (2009). Tecnologia de produção da soja. Editora Mecenas, Porto Alegre, 314.

Silva JA (2013). Avaliação do Programa Nacional de Produção e Uso do Biodiesel no Brasil-PNPB. Rev. Política Agríc. 22: 18-31.

Souza LCF, Zanon GD, Pedroso FF and Andrade LHL (2009). Teor de proteína e de óleo nos grãos de soja em função do tratamento de sementes e aplicação de micronutrientes. Cienc. Agrotecnol. 33: 1586-1593.

Suarez PAZ, Santos ALF, Rodrigues JP and Alves MB (2009). Biocombustíveis a partir de óleos e gorduras: desafios tecnológicos para viabilizá-los. Quím. Nova 32: 768-775. 